\title{
Determination of Insulin Specific IgE in Serum of Diabetic Patients by Solid-Phase Radioimmunoassay
}

\author{
K. Falholt \\ Novo Research Institute, Bagsværd, Denmark
}

\begin{abstract}
Summary. A solid-phase assay system for quantitative measurement of insulin specific IgE has been developed. Insulin specific IgE and IgG are bound to insulin covalently coupled to Sepharose particles. After a washing procedure which removes unbound immunoglobulins, ${ }^{125}$ I-anti-human IgE-rabbit globulin is added to the Sepharose to determine the amount of bound IgE. The use of standardized ${ }^{125} \mathrm{I}$-anti-humanIgE-globulin permits quantitation against a calibration curve of IgE and expression as units $/ \mathrm{ml}$. No cross-reactivity of IgG was found. Insulin specific $\operatorname{IgE}$ was determined in the sera of diabetic patients. Patients treated with porcine or mixed species purified insulin (monocomponent MC) did not differ significantly from a non-diabetic control group, whereas serum samples taken from patients treated with crystallized insulin preparations showed a significantly higher level of insulin specific $\operatorname{IgE}(p<$ 0.05 ). Twenty-four patients with generalized insulin allergy and eight patients with immunological insulin resistance also had considerably higher values of $\operatorname{IgE}$ antibodies than the control group ( $p<0.001$ and $p<$ 0.005 , respectively). No correlation was found between the concentration of insulin specific $\operatorname{IgE}$ and $\mathrm{IgG}$ in individual sera and the level of insulin specific $\mathrm{IgE}$ was independent of the total IgE. In all cases of allergy elicited by purified insulin (monocomponent MC), it was ascertained that the diabetic patients in question had received less pure insulin during earlier treatment.
\end{abstract}

Key words: Insulin specific $\operatorname{IgE}$ antibodies $\left(\operatorname{IgE} E_{I}\right)$, insulin allergy, insulin resistance, crystalline insulin, purified insulin (monocomponent MC).

A few reports have shown that insulin specific $\operatorname{IgE}$ $\left(\operatorname{IgE}_{\mathrm{I}}\right)$ may be induced by treatment with crystalline insulin and is present not only in diabetic patients with allergic symptoms, but also in diabetics without allergy. Patterson et al. [1, 2] confirmed in 1969 in six patients that spontaneous insulin allergy was caused by antibodies of the IgE class. Kumar et al. [3, 4], using a paper radioimmunosorbent technique, investigated insulin treated diabetics and could not detect $\mathrm{IgE}_{\mathrm{I}} \mathrm{ti}-$ tres in non-diabetic controls, whereas detectable $\mathrm{IgE}_{\mathrm{I}}$ was found in all the diabetics. Twelve patients with generalized allergy and resistance had significantly higher titres. Nakagawa et al. [5] described a modification of Wide's radio-allergosorbent test [6] and found higher values in six patients with insulin allergy than in normal persons or insulin treated diabetics without insulin allergy. Velcovsky et al. [7] used a direct method as well as a method calculating the $\mathrm{IgE}_{\mathrm{l}}$ as the difference between the total $\mathrm{IgE}$ determined by Pharmacia's paper radioimmunosorbent test and the residual IgE after removal of $\operatorname{IgE}_{\mathrm{I}}$. This technique allowed the results to be given in $\mathrm{U} / \mathrm{ml} \operatorname{IgE}$, thus facilitating the comparison of results obtained in different laboratories.

The aims of the present study were to establish a routine method for the determination of $\operatorname{IgE}_{\mathrm{I}}$, to compare the $I g E_{I}$ levels in groups of diabetics treated with insulin of different purity, and finally to investigate the $\operatorname{IgE} \mathrm{E}_{\mathrm{I}}$ levels in patients with insulin allergy and resistance.

\section{Patients and Methods}

\section{Patients}

Sera from the following groups of patients were analysed: Control group and Type 1 (insulin-dependent) diabetic patients treated with insulin of different purity and with no overt local or systemic allergy to insulin: 25 non-diabetic subjects, 20 Type 1 (insulin-dependent) diabetic patients treated for 1 year with four to five times crystallized (porcine and bovine) insulin preparations, and 20 Type 1 (insulin-dependent) diabetic patients treated exclusively with porcine purified insulin (monocomponent MC) for 2 years.

Insulin allergic and resistant patients: (a) 24 patients who have had episodes of generalized allergic reactions to insulin, ranging from urticaria and local oedema to anaphylactic reactions, (b) 17 patients where the only complaint was redness at the injection site and which rapidly disappeared, (c) eight immune-type insulin resistant patients with a daily insulin requirement $>150 \mathrm{U}$. 
Table 1. Insulin specific $\operatorname{IgE}\left(\operatorname{IgE}_{\mathrm{I}}\right)$ in non-diabetic subjects and Type 1 diabetic patients

\begin{tabular}{ll}
\hline & $\operatorname{IgE}_{\mathrm{I}}(\mathrm{U} / \mathrm{ml})$ \\
\hline $\begin{array}{l}\text { Non-diabetics }(n=25) \\
\text { Type 1 diabetic patients }\end{array}$ & $0.6 \pm 0.1$ \\
$\quad \begin{array}{l}\text { Treated 1 year with four to five times } \\
\quad \text { crystallized insulin preparations }(n=20)\end{array}$ & $1.2 \pm 0.2$ \\
$\quad \begin{array}{l}\text { Treated exclusively with purified porcine } \\
\text { insulin (monocomponent MC) }\end{array}$ & \\
$\quad$ for 2years $(n=20)$ & $0.4 \pm 0.1$ \\
$\begin{array}{l}\text { Treated exclusively with mixed purified } \\
\text { porcine and bovine insulin (mono- } \\
\text { component MC) for 2 years }(n=15)\end{array}$ & $0.3 \pm 0.1$ \\
\hline
\end{tabular}

Results expressed as mean \pm SEM

\section{Methods}

Insulin was coupled to Sepharose particles (Pharmacia Sepharose 4B) and characterized according to Heding [8]. The Sepharose-insulin particles were suspended in a phosphate buffer $(0.04 \mathrm{~mol} / \mathrm{l}$, pH 7.4) containing electrophoretically pure human albumin ( $1 \mathrm{~g} / \mathrm{l}$, Behringwerke, Marburg FGR), thiomersal ( $0.2 \mathrm{~g} / \mathrm{l}$, British Drug Houses, Poole, UK), and $\mathrm{NaCl}(6 \mathrm{~g} / \mathrm{l})$. This buffer is referred to as NaFAM. The final concentration of Sepharose-insulin was $1 \mathrm{mg}$ bound insulin/ml. All standards and samples were diluted in NaFAM and run in duplicate. Sepharose-insulin suspensions $(500 \mu \mathrm{l})$ and sera samples $(500 \mu \mathrm{l})$ were shaken overnight at $4{ }^{\circ} \mathrm{C}$ whereby total binding of both insulin specific $\operatorname{IgG}\left(\operatorname{IgG}_{\mathrm{I}}\right)$ and $\mathrm{IgE}_{1}$ occurred. After washing three times with $2 \mathrm{ml} \mathrm{NaFAM}$ followed each time by centrifugation $(2000 \times \mathrm{g}$ for $10 \mathrm{~min})$, the Sepharose-insulin antibody complex was incubated overnight with $100 \mu \mathrm{l}$ of ${ }^{125} \mathrm{I}$-anti-IgE globulin solution $(4.2 \mathrm{mCi} / \mathrm{mg}, 0.16 \mu \mathrm{g} / \mathrm{ml}$, Pharmacia, Uppsala, Sweden). With each series of samples, ${ }^{125}$ I-anti-IgE globulin $(100 \mu \mathrm{l})$ was added to a range of Pharmacia standards $(0-50 \mathrm{U} / \mathrm{ml}$ $\operatorname{IgE}, 100 \mu \mathrm{l})$ to obtain a calibration curve.

After a further washing procedure $(3 \times 2 \mathrm{ml} \mathrm{NaFAM})$ for both samples and standards, the radioactivity was counted in a gamma well counter and the results were calculated from the calibration curve and expressed in $\mathrm{U} / \mathrm{ml}$ of IgE.

Possible interference in the assay by $\operatorname{IgG}$ was investigated by determining the $\operatorname{IgE} E_{1}$ in (a) 10 patients with $\mathrm{IgG}_{1}>0.5 \mathrm{mU} / \mathrm{ml}$ and (b) 10 patients with $\operatorname{IgG}_{1}<0.02 \mathrm{mU} / \mathrm{ml}$. The insulin binding to IgG was determined by the immuno-electrophoretic method of Christiansen [9]. Total IgE was determined by the Pharmacia PRIST method.

\section{Results}

The detection limit of the assay, defined as the smallest amount of $\operatorname{IgE}$ which can be distinguished from zero with $99 \%$ confidence limits, was $0.7 \mathrm{U} / \mathrm{ml}$ calculated from 10 calibration curves. The within assay variation expressed as a constant standard deviation (SD) was $0.4 \mathrm{U} / \mathrm{ml}$ (range $0-20 \mathrm{U} / \mathrm{ml}, n=20$ ), and the between assay variation had a SD of $0.5 \mathrm{U} / \mathrm{ml}$ (range $5-10 \mathrm{U} / \mathrm{ml}, n=20$ ).

Multiple estimations on a serum with high $\operatorname{IgE}_{\mathrm{I}}$ content at varying dilutions (range $1: 10-1: 100$ ) gave values of $\mathrm{IgE}_{\mathrm{I}}$ ranging from $10.2-14.4$, mean $12.0 \pm$ $1.4 \mathrm{U} / \mathrm{ml}( \pm \mathrm{SD}, n=6)$. The non-specific binding to Sepharose without insulin was $0.9 \pm 0.4 \%$ bound radioactivity (mean $\pm \mathrm{SD}$ ) and corresponding values for non-specific binding to an IgE-free serum (Pharmacia) was $1.5 \pm 0.6 \%$ bound radioactivity.

In Type 1 diabetic patients with $\operatorname{IgG}_{I}>0.5 \mathrm{mU} /$ $\mathrm{ml}, \mathrm{IgE}_{\mathrm{I}}$ was found to be $0.2 \pm 0.1 \mathrm{U} / \mathrm{ml}$ (mean \pm $\mathrm{SD}, n=10$ ), and in a similar group of diabetics with $\mathrm{IgG}_{1}<0.02 \mathrm{mU} / \mathrm{ml}$, the values were $0.3 \pm 0.3 \mathrm{U} / \mathrm{ml}$ (mean $\pm \mathrm{SD}, n=10$ ). Since there is no significant difference between these two groups $\operatorname{IgG}_{I}$ does not interfere in the assay in the concentrations found here.

In five serum samples without $\mathrm{IgG}_{\mathrm{l}}$, recovery experiments showed $84 \pm 3 \%$ at the level of $9.3 \mathrm{U} / \mathrm{ml}$ $\operatorname{IgE}_{\mathrm{I}}$ and $84 \pm 3 \%$ at the level of $13.6 \mathrm{U} / \mathrm{ml} \mathrm{IgE}$. In five serum samples containing $\operatorname{IgG}_{1}(0.5-2.2 \mathrm{mU} / \mathrm{ml})$, recovery experiments gave identical results. In five serum samples with $\mathrm{IgG}_{\mathrm{I}}$ ranging from $5.7-23.9 \mathrm{mU} /$ $\mathrm{ml}$, the recovery was only $51 \pm 30 \%$ at the level $9.3 \mathrm{U} / \mathrm{ml} \lg E_{I}$ and $44 \pm 31 \%$ at the level $13.6 \mathrm{U} / \mathrm{ml}$ $\mathrm{IgE}_{\mathrm{l}}$. Using ample amounts of Sepharose for these determinations the recovery rate was about $85 \%$; if the $\mathrm{IgG}_{\mathrm{I}}$ level is $>2.0 \mathrm{mU} / \mathrm{ml}$ somewhat more Sepharose-insulin suspension than indicated in the method description is necessary to ensure complete antibody binding.

Table 1 gives the results of the $\operatorname{IgE}_{\mathrm{I}}$ analyses of sera from Type 1 diabetic patients treated with insulin of different purity. Sera from Type 1 diabetic patients treated at the same time with $5 \times$ crystallized insulin preparations show a significantly higher level of $\operatorname{IgE} E_{I}$ than non-diabetic subjects $(p<0.05)$ and diabetics treated with purified insulin (monocomponent $\mathrm{MC}$ ) $(p<0.001)$.

The insulin-allergic patients have elevated levels of $\operatorname{IgE}_{\mathrm{I}}$ (Fig. 1) ranging from 1.0-18.4 U/ml $(7.1 \pm$ 1.2 ; mean $\pm \mathrm{SEM})$ in the group with manifest symptoms $(n=24)$ compared with both the non-diabetic subjects and the diabetic patients treated with purified insulin (monocomponent MC) $(p<0.001)$. The group where the clinical complaints were limited to local redness did not show significantly higher $\operatorname{IgE}_{\mathrm{I}}$ levels than the non-diabetic subjects and diabetics treated with purified insulin (monocomponent MC). In the insulin resistant group, one patient had an $\operatorname{Ig} E_{\mathrm{I}}$ level of $18 \mathrm{U} / \mathrm{ml}$, the other eight insulin-resistant patients showed a significantly higher level of $\operatorname{IgE} E_{I}$ than the non-diabetic subjects and the diabetics treated with purified insulin (monocomponent MC) $(p<$ 0.005 ). The $p$-values are calculated according to the Wilcoxon-Mann-Whitney rank sum test. Figure 2 shows the ratios of $\frac{\mathrm{IgE}_{\mathrm{I}}}{\mathrm{IgG}_{\mathrm{I}}}$ obtained in the various groups of patients.

We have excluded patients with $\mathrm{IgG}_{\mathrm{I}}<0.034$ $\mathrm{mU} / \mathrm{ml}$ because levels below this limit do not represent significant binding relative to that found in normal subjects [9]. Only eight out of the 20 diabetics treated with purified insulin (monocomponent $\mathrm{MC}$ ) had $\mathrm{IgG}_{\mathrm{I}}$ values $>0.034$. No statistically significant 


\section{$\lg \mathrm{E}_{\mathrm{l}} \mathrm{U} / \mathrm{ml}$}
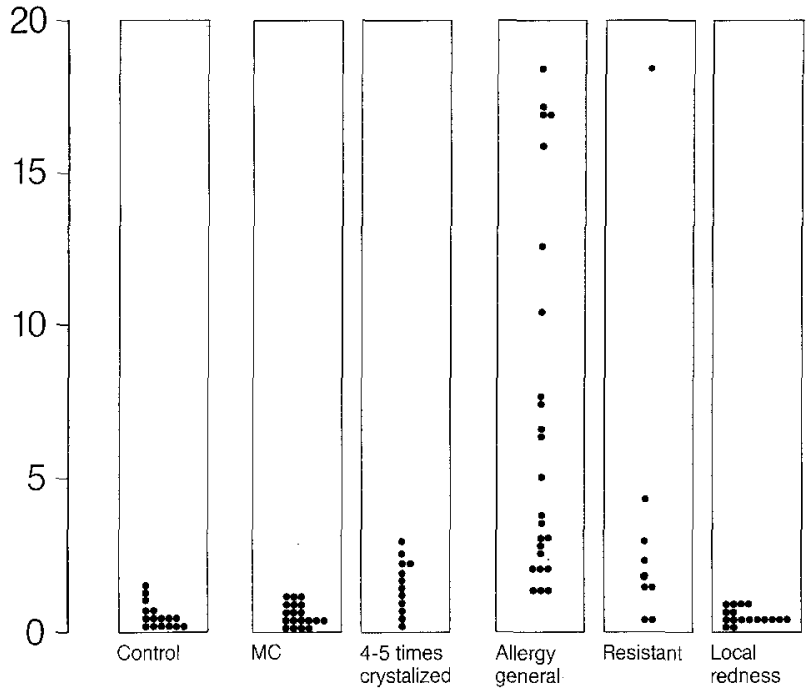

Fig. 1. The distribution of immunoreactive $\operatorname{IgE}\left(\operatorname{IgE} E_{1}, U / m l\right)$ in the investigated groups of Type 1 (insulin-dependent) diabetic patients and control subjects. $M C=$ monocomponent insulin

difference can be shown between the ratio of $\frac{\operatorname{IgE}_{I}}{\operatorname{IgG}_{I}}$ in the different groups ( $5 \%$ level). No correlation can be shown between the total $\mathrm{IgE}$ and the $\operatorname{IgE} \mathrm{E}_{\mathrm{I}}$.

\section{Discussion}

The solid-phase radioimmunoassay used to measure $\operatorname{IgE}_{I}$ appears to be specific, sensitive and not subject to interference by $\operatorname{IgG}_{\mathrm{I}}$. Besides allowing immediate comparison of intra-laboratory results, the inclusion of an IgE calibration curve allows the results to be expressed in $\mathrm{U} / \mathrm{ml}$, which is not possible with the methods of Kumar et al. [3, 4] and Nakagawa et al. [5]. Recently, Hamilton et al. [10] have described a method similar to ours, demonstrating high $\mathrm{IgE}_{\mathrm{I}}$ in three allergic patients and in one of three patients with insulin resistance. Their results were reported in $\mathrm{ng}=\mathrm{U} / \mathrm{ml}$, determining the $\operatorname{IgE} E_{I}$ level as the difference of $\operatorname{IgE}$ measured before and after removal of $\mathrm{IgE}_{\mathrm{I}}$ from the serum sample. Quantitation of the $\operatorname{IgE}_{\mathrm{I}}$ in this way is rather time comsuming in a routine assay. An advantage of our method is that it allows calibration in routine assays. Kumar [3] reported low ratios of $\frac{\mathrm{IgE}_{I}}{\mathrm{IgG}_{\mathrm{I}}}$ in insulin allergic patients compared with insulin resistant diabetic and Type 1 diabetic patients without these complications. We have not been able to verify this finding and thereby confirm Kumar's suggestion that the circulating $\operatorname{IgG}_{\mathrm{I}}$ antibodies could act as $\frac{\lg E_{1}}{\lg G_{1}}$
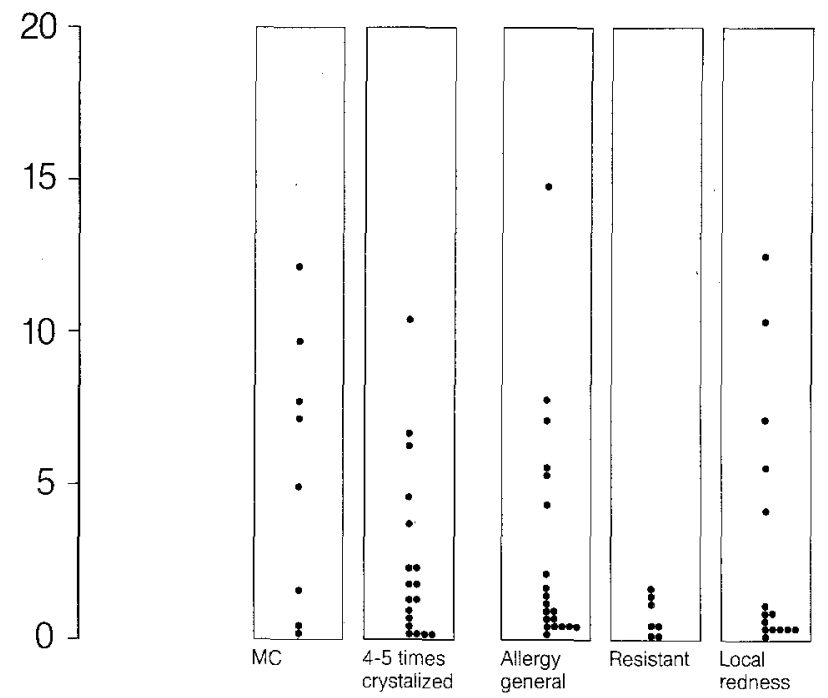

Fig. 2. Ratio of immunoreactive $\operatorname{IgE} /$ immunoreactive $\operatorname{IgG}$ ( $\operatorname{IgE}_{\mathrm{I}} /$ $\mathrm{IgG}_{\mathrm{I}}$ ) in the investigated groups of Type 1 (insulin-dependent) diabetic patients. Only patients with $\operatorname{Ig} G_{I}<0.034$ are included. There is no significant difference between the various groups investigated. $M C=$ monocomponent insulin

'blocking' antibodies and render some protection against $\mathrm{IgE}_{\mathrm{I}}$ mediated reactions. This theory has also been supported by Revatelle and Ovary [11] and Halper and Metzger [12]. Witters et al. [13] contributed to the theory of $\mathrm{IgG}_{1}$ as 'blocking' antibodies, stating that they have demonstrated rising levels of $\mathrm{IgG}_{\mathrm{I}}$ in some patients during desensitization.

Our results may explain the fact that Kumar [3] found a difference between Type 1 diabetic patients without allergy and normal subjects, whereas Nakagawa et al. [5] found the two groups identical. Nakagawa's Type 1 diabetic patients were treated with purified insulin (monocomponent MC). Our results show no difference between the non-diabetic control group and patients treated with purified insulin (monocomponent $\mathrm{MC}$ ). Kumar's patients may have received crystalline insulin and therefore showed the same difference from the normal control group as we too have demonstrated between diabetic patients treated with crystalline insulin and normal subjects (Table 1).

The fact that all patients with generalized allergy had significantly higher values suggests the usefulness of our method as a diagnostic aid in vitro for the choice of treatment. This is supported by the fact that one of the allergic patients showed a decrease in $\operatorname{IgE}_{I}$ after changing insulin ( $\mathrm{NPH} \rightarrow$ Lente $\mathrm{MC}$ ), resulting in disappearance of the clinical allergic symptoms, a finding similar to the case described by Nakagawa et al. [5]. In another allergic patient the gradual decrease 
in $\operatorname{IgE}_{\mathrm{I}}$ after desensitization was again paralleled by the disappearance of clinical symptoms. Kumar [3] has also demonstrated the same response after desensitization. Our data confirm Kumar's [3] and Velcovsky et al.'s [7] earlier observations that the level of $\mathrm{IgE}_{\mathrm{T}}$ is not correlated to the degree of severity of the allergic manifestations. One patient had severe allergic reactions in spite of low $\operatorname{IgE} E_{1}$ levels $(1.2 \mathrm{U} / \mathrm{ml})$, whereas another patient, whose $\mathrm{IgE} \mathrm{E}_{\mathrm{I}}$ levels were considerably increased $(16.8 \mathrm{U} / \mathrm{ml})$, only showed moderate allergic reactions.

Velcovsky et al. [7] have shown that there is no correlation between the content of total $\mathrm{IgE}$ and $\operatorname{Ig} \mathrm{E}_{\mathrm{I}}$, a result we can confirm. Thus the assay for total $\operatorname{IgE}$, still widely used, is, in fact, irrelevant in demonstrating the presence of insulin allergy.

Leslie [14] reported a case of generalized allergic reaction to $\mathrm{MC}$-insulin, where his patient had been treated with insulin for a short period 11 years earlier. Our patient material confirms that allergic reactions are elicited even by purified insulin (monocomponent $\mathrm{MC}$ ), but only in patients with a history of previous, perhaps only very brief, insulin treatment. Six of our patients developed allergy to purified insulin (monocomponent MC); they all had a history of earlier disrupted conventional insulin therapy.

Kurtz and Nabarro [15], Grüneklee [16] and Kahn and Rosenthal [17] support our conclusion by their statements that the institution of insulin therapy needs very careful thought, so as to avoid instances of discontinued treatment leading to an unwanted booster effect on resumed therapy. Grüneklee [16], Andreani et al. [18], Reisner et al. [19], Federlin et al. [20] and Vinik et al. [21] confirm the importance of using the purest insulin available in order to avoid allergic reactions created by a possible adjuvant effect of the impurities. Alberti and Natrass [22] came to the same conclusion, advocating the use of insulin preparations of low antigenicity.

In conclusion, our results confirm the likelihood that the use of highly purified insulins, by minimizing the risk of inducing insulin antibody formation of the IgE type, will not be associated with allergic problems (provided the patients are not already immunized).

Acknowledgements. I should like to thank Lise G. Heding for her never failing encouragement and invaluable advice. The excellent technical assistance of Mrs. E. N. Jensen and the efficient secretarial assistance of Mrs. K. Rimmer is gratefully acknowledged. Mrs. K. Larsen and Mrs. B. Jensen are thanked for tolerant correcting of the English and skillful statistical analyses, respectively.

\section{References}

1. Patterson R, Lucerna G, Metz R, Robert M (1969) Reaginic antibody against insulin. Demonstration of antigenic destruction between native and extracted insulin. J Immunol 103: 1061-1071
2. Patterson R, Mellis CJ, Roberts M (1973) Immunologic reactions against insulin. IgE anti-insulin, insulin allergy and combined $\operatorname{IgE}$ and $\mathrm{IgG}$ immunologic insulin resistance. J Immunol 110: $1135-1145$

3. Kumar D (1977) Anti-insulin IgE in diabetics. J Clin Endocrinol Metab 45: 1159-1164

4. Kumar D, Rosenquist RJ, Parameswaran V (1979) Insulin allergy. Reagenic antibodies to insulin and proinsulin. J Clin Metab 49:252-254

5. Nakagawa S, Saito N, Nakayama H, Sasaki T, Watanabe T, Aoki S (1978) Detection of IgE insulin antibody with radioallergosorbent test. Diabetologia 14:33-38

6. Wide L (1967) Diagnoses of allergy by an in-vitro test for allergic antibodies. Lancet 2: 1105-1107

7. Velcovsky HG, Schmidt G, Jonatha EM, Federlin K (1977) Untersuchung der Immunogenicität von verschiedenen Insulinen durch die spezifische IgE Bestimmung. Verh Dtsche Ges Innere Med 83:1429-1432

8. Heding LG (1975) Radioimmunological determination of human C-peptide in serum. Diabetologia 11:541-548

9. Christiansen AaH (1973) Radioimmunoelectrophoresis in the determination of insulin binding to IgG. Methodological studies. Horm Metab Res 5: 147-154

10. Hamilton RG, Rendell M, Adkinson NF (1980) Seralogical analyses of human $\operatorname{IgG}$ and $\operatorname{IgE}$ anti-insulin antibodies by solidphase radioimmunoassays. J Lab Clin Med 96: 1022-1036

11. Revatelle R, Ovary Z (1973) Competitive effect of homologous IgG or $F_{c}$ in sensitization of rabbits for PCA mediated by reaginic antibodies. J Immunol 111:698-705

12. Halper J, Metzger H (1976) The interaction of $\mathrm{IgE}$ with rat basophile leukemia cells. Inhibition by $\operatorname{IgG}_{\mathrm{a}}$ immune complexes. Immunochemistry 13:907-913

13. Witters LE, Ohman JL, Weir GC, Raymons LW, Lowell FC (1977) Insulin antibodies in the pathogenesis of insulin allergy and resistance. Am I Med 63:703-709

14. Leslie D (1977) Generalized allergic reactions to monocomponent insulin. Br Med J 2: 736-737

15. Kurtz AB, Nabarro JDN (1980) Circulating insulin-binding antibodies. Diabetologia 19:329-334

16. Grüneklee D (1980) Die Insulin Allergie. Intern Welt 12: $442-450$

17. Kahn CR, Rosenthal AS (1979) Immunologic reactions to insulin. Diabetes Care 2: 283-295

18. Andreani D, Lavicoli M, Tamburrano G, Menzinger G (1974) Comparative trials with monocomponent (MC) and monospecies (MS) pork insulin in the treatment of diabetes mellitus. Influence on antibody levels, on insulin requirement and some complications. Horm Metab Res 6:447-454

19. Reisner C, Maut DJ, Cudworth AG (1978) Generalized urtecarea precipitated by change to highly purified porcine insulin. Brit Med J 2:56

20. Federlin K, Jonatha EM, Hupfeld P, Schroeder E (1974) Erfahrungen mit chromatographisch gereinigten Insulin bei Patienten mit erhöhtem Insulin Bedarf, Insulin Allergie oder Lipodystrophie. Therapie Woche 24: 1940-1953

21. Vinik A, Joffe BI, Seftel HC, Distiller LA, Jackson WPM (1976) Clinical aspects of monocomponent insulins in the treatment of diabetes. S Afr Med J 50:587-591

22. Alberti KGMM, Natrass M (1978) Highly purified insulins. Diabetologia 15:77-80

Received: 15 May 1981

and in revised form: 11 November 1981

Karen Falholt

Novo Research Institute

Novo Allé

DK-2880 Bagsværd, Denmark 